\title{
The Problem of Public Accountability in Village Governance in Rural Enrekang, Indonesia
}

\author{
${ }^{1}$ NURLINAH, ${ }^{2}$ HARYANTO, ${ }^{3}$ ERWIN MUSDAH \\ 1, 2 Department of Politics and Government, Hasanudin University, Jl. Perintis Kemerdekaan Km. 10 Makassar \\ 3 STIA LAN Makassar, JI. A.P. Pettarani No 61 Makassar \\ email: ${ }^{1}$ nurlinah@unhas.ac.id; ${ }^{2}$ harymusi@unhas.ac.id; ${ }^{3}$ erwinmusdah@gmail.com
}

\begin{abstract}
This article examines a range of issues in the implementation of village governance to enhance public accountability. Subsequent to village law, a village now has to deal with how to manage government finances by promoting public accountability knowing that public accountability is the spirit of reviving democracy in village government. This study investigates the practice of village fund governance by collecting qualitative data from 9 villages in Enrekang Regency, South Sulawesi. The villages were randomly selected, one village in 9 sub-districts of 12 sub-districts in Enrekang. There were three primary causes of the lack of public accountability, namely: institutional arrangement, social organizations, and local culture. In practice, each cause has a different impact on determining the level of accountability in a village. It implies that the principles of good governance are still not fully embraced by local villagers and village government.
\end{abstract}

Keywords: Public Accountability, Governance, Village Funds, Rural Politics

\section{Introduction}

The question arose after the change in village law applied in Indonesia was the extent of the impact felt by the community and the village government. Law No. 4/2014 or often called the Village Law has forced the government and village communities in Indonesia to present better governance. Particularly, after financial management in all Indonesian villages reached above 1 billion per year. The village government is required to deliver accountability transparently, while the village community is asked to participate in overseeing the accountability. In essence, the village has to manage its governance by establishing accountability in the community. Accountability issue is a trend of government evaluation in developing countries in recent years (Loozekoot \& Dijkstra, 2015). Moreover, it is a spirit in reviving democracy at any level of government (Schmitter \& Karl, 1991), including in the village.

There are recent studies analyzing villages including the complicated problems in governance (Antlöv et al., 2016; Vel et al.,
2016; Salim et al., 2017; Sutiyo \& Maharjan, 2017). Those studies conclude, among others, that the government's response is still low, the lack of accountability control instruments, citizen participation in the legal framework is not optimal, and rural development governance. Village law is also considered to have not yet provided an adequate basis for regulating appropriate village financial management, explicitly preventing corruption (Novrizal \& Podger, 2014: 29), as well as the awareness of law and corruption and development practices in villages in Indonesia (Susan \& Budirahayu, 2018: 26). However, the existing studies are still relatively early and tend to be on the regulatory side, not yet looking further at the issue of public accountability on the side of power relations and institutional mechanisms.

This article aims to explain public accountability on the side of power regulation and institutional mechanisms. This goal is conceptually fundamental to help find various issues related to the village governance in Indonesia. Thus, various recommendations can be made as solutions to problems exist in

Received: March 13, 2018, Revision: September 16, 2018, Accepted: December 16, 2018

Print ISSN: 0215-8175; Online ISSN: 2303-2499. DOI: http://dx.doi.org/10.29313/mimbar.v34i2.3578.332-340

Accredited B based on the decree No.040/P/2014, valid on February, 18, 2014 until February, 18, 2019. Indexed by DOAJ, Sinta, IPI 
the village administration. For this reason, this article has carried out some analyses related to the issue of public accountability from research conducted in the mountain village of Enrekang Regency, South Sulawesi. The study conducted in nine agrarian villages spread over more than half of the sub-districts in the area. In practice, this public accountability is still a problem for the villages, as evidenced by the low knowledge of the apparatus and the village community about what and how to be accountable.

Our explanation of public accountability starts from determining which perspective is used to analyze the village governance. Taking into account that there are entirely different conceptual debates on public accountability, this article chooses to use a political and administrative science perspective. In the next section, this article presents a description of governance practices in nine villages of research objects. Some villages have the same problem, but the whole village has a different polarisation in three main issues which are indicators of this public accountability research. The three indicators aforementioned and further explained in this article are the institutional mechanism, social organization design, and local culture. In the last section, we compiled a simple recommendation to help resolve the public accountability issues of village government.

\section{Research Method}

This article uses qualitative research with a combination of in-depth interview techniques and Focus Group Discussion (FGD) since it is considered the most appropriate in collecting precise data. This research conducted in nine (9) villages in Enrekang, South Sulawesi Province. The villages were randomly selected, one village in 9 subdistricts of 12 sub-districts in Enrekang. Intensive field research was carried out between November-December 2017 and FGDs in January 2018. Data collected was the result of in-depth interviews with key informants of village heads, secretaries, village parliament members (BPD), and villagers.

Data from interviews with key informants were processed and made as the basis for compiling FGD instruments. The FGDs were attended by the Head of Community and Village Empowerment Service, Village Heads, Sub-District Heads, and village facilitators. Focus group discussions were conducted to obtain macro village fund management data at local government level, while the interview data confirmed at village government level (data triangulation). Data collection was also carried out by inventorying data from regional regulations and newspaper archives on village policies issued by regional government.

\section{Public Accountability: In Perspective}

The concept of public accountability fundamentally departs from the concept of accountability, which explains accountability in public sphere. The concept of accountability widely interpreted by social scientists, primarily political and administrative sciences. However, research on accountability is also widely carried out in the perspective of psychology, law, economics, and international relations (Lindberg, 2013; Bovens et al., 2014). There are many diverse definitions of accountability, however, they can not be all accounted. This article will not reiterate various debates regarding conceptual view of accountability, but they can be seen in chapters edited by Bovens, Goodin, and Schillemans (2014). In classical literature, those debates can also be seen in the work of Normanton (1966), Smith \& Hague (1971), McKinney (1981), O'Loughlin \& Michael (1990), and Schedler (1999). In this article, the authors use the perspective of political and administrative sciences.

Based on the perspective of political and administrative sciences, accountability can be defined as relationship between actors and forums where the actor has an obligation to explain and justify his actions, the forum can ask questions and provide judgments, and the actor may face the consequences of his actions (Bovens, 2007: 450). Regarding the development, Bovens, Schillemans and Goodin (2014: 7) explained more specifically about public accountability which interpreted in three forms. First is the openness or transparency, which means that everything is accessible and open to the public. Second, public accountability is mainly related to public problems such as the issuance of public funds, the implementation of public power, or the implementation of public institutions. Third, public accountability can refer to issues of public interest or public responsibility. In short, this perspective emphasizes on governance, where public accountability is seen as a virtue and mechanism within the scope of government (Bovens, 2010). 
Table 1

Villages Profile

\begin{tabular}{lllllll}
\hline No & Villages & $\begin{array}{c}\text { Popu- } \\
\text { lation }\end{array}$ & $\begin{array}{c}\text { Distance } \\
\text { to Regency } \\
\text { Capital } \\
\text { (kilometre) }\end{array}$ & $\begin{array}{c}\text { Village } \\
\text { Fund 2017 } \\
\text { (in million } \\
\text { rupiah) }\end{array}$ & $\begin{array}{c}\text { Village Fund } \\
\text { Allocation } \\
\text { 2017 (in } \\
\text { million } \\
\text { rupiah) }\end{array}$ & Village Category \\
\hline 1 & Pattondonsalu & 2129 & 38 & 785,087 & 246,443 & $\begin{array}{l}\text { Swasembada (self- } \\
\text { sufficient) }\end{array}$ \\
2 & Perangian & 947 & 41 & 779,202 & 244,496 & Swadaya (self-supporting) \\
3 & Bambapuang & 1976 & 12 & 783,661 & 245,974 & Swasembada \\
4 & Ranga & 1027 & 11 & 827,433 & 260,494 & Swadaya (self-supporting) \\
5 & Mandalan & 755 & 46 & 785,860 & 246,058 & Swakarya (self-developing) \\
6 & Buntu Batuan & 777 & 45 & 773,722 & 242,677 & Swakarya (self-developing) \\
7 & Taulan & 1996 & 15 & 778,841 & 244,375 & Swasembada \\
8 & Batu Kedde & 2120 & 48,5 & 804,841 & 253,001 & Swakarya (self-developing) \\
9 & Mata Allo & 1200 & 36 & 796,802 & 250,335 & Swasembada \\
\hline
\end{tabular}

Source: Enrekang Regency in Figures 2017

As mentioned earlier, this article will bring the concept of public accountability from a governance perspective. Public accountability is seen as a power relation and public service mechanism in government system. It examines how the governments carry out their duties of accountability mechanism transparently and openly, while the public or public as a forum is actively involved in providing an assessment of the tasks done by government. By this framework of analysis, political science perspective will be used in conjunction with the administrative science perspective, in which analyses in the following sections describe problems related to power relations and the provision of mechanisms for accountability of public services.

\section{The Use of Village Fund in Nine Vil- lages}

The nine villages that we studied located in nine sub-districts of Enrekang Regency, which are Pattondongsalu, Taulan, Ranga, Bambapuang, Buntu Batuan, Peragian, Mata Allo, Mandalan, and Batu Ke'de respectively. The locations of these villages are entirely mountainous areas, where the majority of the villagers work as horticultural farmers. There are six villages far enough from district's capital, but fortunately the road access is good enough to reach these villages. The nine villages were distributed into categories based on the Minister of Home Affairs Regulation No. 84/2016: namely two swadaya (selfsupporting) villages, three swakarya (self-

Table 2

Financial Budget of Villages

\begin{tabular}{|c|c|c|c|c|}
\hline No & Villages & $\begin{array}{l}\text { Village Fund } 2017 \text { (million } \\
\text { rupiah) }\end{array}$ & $\begin{array}{l}\text { Village Fund Allocation } \\
2017 \text { (million rupiah) }\end{array}$ & $\begin{array}{l}\text { Total } \\
\text { (million rupiah) }\end{array}$ \\
\hline 1 & Pattondonsalu & 785,087 & 246,443 & $1.031,530$ \\
\hline 2 & Perangian & 779,202 & 244,496 & $1.023,698$ \\
\hline 3 & Bambapuang & 783,661 & 245,974 & $1.029,635$ \\
\hline 4 & Ranga & 827,433 & 260,494 & $1.087,927$ \\
\hline 5 & Mandalan & 785,860 & 246,058 & $1.031,918$ \\
\hline 6 & Buntu Batuan & 773,722 & 242,677 & $1.016,399$ \\
\hline 7 & Taulan & 778,841 & 244,375 & $1.023,216$ \\
\hline 8 & Batu Kedde & 804,841 & 253,001 & $1.057,842$ \\
\hline 9 & Mata Allo & 796,802 & 250,335 & $1.047,137$ \\
\hline \multicolumn{4}{|c|}{ Average } & $1.038,811$ \\
\hline
\end{tabular}


developing) villages, and four swasembada (self-sufficient) villages (see table 1 ). The amount of village financial budgets (village funds and village fund allocations) they manage is quite large on the average of 1.038 billion rupiahs (see table 2 ). The financial accountability reports of nine villages in 2016 and 2017 have been received by local government and the community. So far no data has been found on the rejection of village government report, although the village head was asked to revise the accountability report for several times.

Financial management in these nine villages was carried out based on the Minister of Home Affairs Regulation No. 113/2014 concerning Village Financial Management. The management of village finance is undertaken through the stages of planning, implementation, administration, reporting, and accountability. The planning process in nine villages is carried out through the village development planning (musrembang) mechanism. Prior to the musrembang at village level, hamlet heads held hamlet meetings to identify community needs in each hamlet. The results of hamlet meetings were written in documents and discussed in village meetings. The musrembang at village level was attended by hamlet heads, village officials, BPD (village council), representatives of sub-district governments, village assistants, and community leaders selected based on religious elements (imam), education (teacher/headmaster), women activities (PKK), and farmer groups. The number of people involved in village development is quite diverse ranging from $1.08 \%$ to $5.30 \%$ of total population in the village (see table 3 ).

Table 3

Attendance of Musrembang 2017

\begin{tabular}{lllll}
\hline No Villagers & $\begin{array}{l}\text { Number of } \\
\text { Residents } \\
\text { Present }\end{array}$ & $\begin{array}{l}\text { Popu- } \\
\text { lation }\end{array}$ & $\begin{array}{l}\text { Per- } \\
\text { cent- } \\
\text { age } \\
(\%)\end{array}$ \\
\hline 1 & Pattondonsalu & 23 & 2129 & 1,08 \\
2 & Perangian & 46 & 947 & 4,86 \\
3 & Bambapuang & 28 & 1976 & 1,42 \\
4 & Ranga & 44 & 1027 & 4,28 \\
5 & Mandalan & 40 & 755 & 5,30 \\
6 & Buntu-Bantuan & 27 & 777 & 3,47 \\
7 & Taulan & 26 & 1996 & 1,30 \\
8 & Batu Kedde & 57 & 2120 & 2,69 \\
9 & Mata Allo* & - & 1200 & 1,08 \\
\hline
\end{tabular}

Source: processed from the archives of each village $*$ there is no archive.
In general, there are two methods of decision making in village development, namely through ranking and review of the Village Medium Term Development Plan (RPJM). The ranking method is done by giving priority values to each proposal from the hamlets and then calculating the highest value that will become a priority to be proposed as a village program. The document review method is carried out by reviewing village RPJM documents contained what programs should be carried out in the next fiscal year. Between these two methods, the ranking method is the most widely used by villages in Enrekang.

Administration of village management regulates problems of village financial accounting and taxes. Data shows that all villages have general cash books, tax aides, and account books. These documents are needed in reporting and accountability, especially if there is a financial audit in the village. However, regarding managing the general cash book and tax aides, the majority of villages do not routinely fill out cash books. Usually, the cash book is filled before the reporting period. Only two villages from nine villages routinely filled out the general cash book and reported the development of village finance to the village head through the process of closing the book. In 2016, several villages have used the village financial system application (Siskeudes) to administer village finance. In 2017, this application is required to be used by all village governments in Enrekang Regency.

At the reporting stage, the village government was asked to report the realization of budget use in every semester. Data showed that all villages have completed the reports on realisation of stages 1 and 2 . The village government should make this important document because it relates to the accountability and budget disbursement. In practice, this budget realization report often goes unreported (in per semester) due to the late of budget disbursement. Village governments sometimes experience difficulties in compiling reports because the reporting format often follows the will of the examination officials. In 2016 alone, the village government noted that there were three different reporting formats from Regional Inspectorate, the Supreme Audit Agency (BPK), and the Community and Village Empowerment Service (DPMD).

The government's financial responsibility 
is in the form of accountability report on the realization of APBDs. This report is a part of and can not be separated from the report on the implementation of village government. Based on the Minister of Home Affairs Regulation No. 113/2014 concerning Village Financial Management, the accountability report for the realization of regional budget must be determined by village regulations, submitted to the regent at the end of the fiscal year and informed in writing to the community. Other reports attached to the accountability of APBDs' realization were a report on the village wealth as well as a report on the government's program in the village.

In practice, all villages make a report on the accountability of budget realization and submitted to the regent. However, reports on village's wealth and government programs held in the village were not made separated by the village government. Likewise, the accountability report on budget realization made by the village government is not disseminated in writing to the community as mandated by the Minister of Home Affairs. Some village officials did not understand when they asked about village wealth report documents and local government programs reports. It indicates that the village government does not understand the rules that require the village government to create the documents. Regarding the obligation to inform the accountability report on budget realization to the village community, some village officials explained that there was no such obligation. The answers from the village government apparatus can be understood as a lack of understanding and ignorance of the rules.

Explanation regarding the management of village finance above has been described starting from the stages of planning, implementation, administration, reporting, and accountability. In principle, it is carried out based on regulations that have been determined in the village law, but various problems are found, especially in institutional mechanisms and citizenship forums. The following explanation describes this issue through administrative and political perspectives.

\section{The Weakness of Institutional Mechanism}

There are several problems occurred in the institutional mechanism in embodying public accountability. First is the issue of who must be responsible and attend the accountability forum. Provisions in the village law contain a broad understanding so that various interpretations could be emerged. The consequence is that the understanding of village government regarding who is responsible and invited to the accountability forum should be conveyed to anyone who knows the accountability report of village government. Each village has a different understanding of to whom the report must be submitted. The most visible difference is in the question of whether the whole community is an actor of budgeting, so it is necessary to know the accountability report of the village government.

Some villages consider that the community can be represented only by BPD members so that if BPD members know the village government accountability report, then the whole community knows the report. The village government with this understanding assumes that the accountability report does not have to be known by the entire village community because there are no rule that requires it.

The second problem is the understanding of village government actors who consider that the community needs to know in a limited way about the accountability reports of the village government. The limitation found in general is in reports on the realization of activities funded from village finance and total costs used in village government activities. It occurred in villages that regularly report their activities to the community in public forums such as ceremonies or religious activities. The accountability mechanism in this model is delivered informally.

The next problem was also found in the villages which defined all community as actors of village government budgeting, so that it was necessary for all to know the village government's financial accountability report. Village governments with this understanding are those who always and keep conveying the development of village finance at meetings and diversity forums until the village government program is implemented. This practice is only found in War Village. The village head stated that the Budget Plan for working project or government activities was always carried out during construction projects and discussed with the village community about how the budget should be managed.

The fourth problem relates to institutional 
management where all management processes determine the quality of village government accountability. The planning phase plays a vital role in this institutional mechanism. The things that must be accounted for are the things being agreed upon in the planning. In the planning mechanism, all villages have carried out participatory planning in stages from hamlet level to village level. Viewed from the aspect of representation, it tends to represent the existed elements in society. Likewise, from the aspect of accommodation and citizens' interests, in general, it tends to accommodate suggestions and citizens' interests through musrembang. However, there is also a tendency to accommodate the short-term citizens' interests. Data shows that the management of village funds in nine villages is not oriented towards achieving village vision and mission. It can be seen from the inconsistency between the vision and mission of the village and the programs/ activities that will be carried out. There is even a tendency for indicative programs in all villages to use the same format which makes programs and activities look the same, even though the vision and mission of each village is different. Being positioned as a supplementary document, there is no explicit effort from all elements to achieve village's vision and mission.

Village financial management practices show a tendency to place more emphasis on administrative accountability and override public accountability. The village government prioritizes accountability reports to local and central government rather than the community. It can be understood since local and central government have the authority to disburse the budget, so that the village government assume that the managed village funds come from local and central government. Both village funds and ADD (village funds budget) are public money. The central and regional governments are only channels for public money, so that what should be put forward is accountability to the village community.

The issue of institutional mechanisms in nine villages is still relatively weak. Previous studies had photographed this issue before the village law was published, where there was a severe power imbalance between institutions in the village (Sutiyo \& Maharjan, 2014: 164). Another problem that we will discuss in the next section concerns the weakness of citizenship forums, where the determinism design of local social and cultural organisations is needed in building public accountability in community.

\section{Social Organization and Local Cul- ture: the Weakness of Civic Forum}

One way for democracy to work better is to build a civic culture (Putnam et al., 1993; Klofstad, 2011). Civic culture is a forum or community parliament deals with political gatherings (informal discussions) in social networks such as neighbors, colleagues, family members, and others who are present in social environment. The issue of social capital has indeed long been a hallmark of village governance in Indonesia (Bebbington et al., 2006). It includes the influence of patronage and clientelism of rural communities, such as the influence of village heads and other charismatic figures (Berenschot \& Sambodho, 2017; Haryanto, 2017). The involvement of ordinary people to participate in developing policies in the village has also not been seen. This has been a criticism of village governance long before the village law was implemented (Antlöv, 2003). Public accountability itself demands and ensures that anyone can be involved in compiling and overseeing public policy. However, on the other hand, culture and governance are part of the problem in Indonesian villages so far (Bebbington, et al., 2004; Sutiyo and Maharjan, 2014).

In nine villages, there were problems related to the weakness of citizenship forums involved in public accountability. We explore the villagers' knowledge and participation in the reports made. In this element, it can be seen whether the active villagers access the accountability report document. However, not many of the community members want to see and access the report documents. Regarding community knowledge, it was found that out of 17 informant villagers, 12 informants did not know the planning documents consisting of Village RPJM, Village RKP, and APB Desa. Whereas, regarding community access to the report, it was found that out of 17 villagers who were informants, 14 informants said they had never seen the documents.

Meanwhile, knowledge and accessibility to village government accountability reports are much lower. Data shows that of the 17-people interviewed, there were only two people who knew the report of village's government realization budget in the first and second semester. Some of the people interviewed explained that they were only 
invited during the planning meeting but were not invited to the accountability forum. In this case, the village government in general explained that these documents were always available at the village office and would be indicated if there were questions from the village community. Although these documents can be accessed, there is no member of community wants to access them.

This condition was exacerbated by the culture of people who still tended to consider taboo to ask questions about village finance to the government. The results of interviews with the community indicate that they felt inappropriate or not entitled to ask financial matters to the government. Financial issues are still considered something sensitive so that people are more likely to avoid financial questions. Also, the fact that the kinship relationship is still very close between the village government and the village community causes the community to be more careful in discussing village financial issues.

In all villages, all community members consider village officials to be their close relatives, so accountability mechanisms often do not work effectively. The culture of mountain village communities that tend to be homogeneous makes values such as shame, respect, and admiration for village leaders become factors in the low participation of citizens to be active and critical to village financial accountability. If there are critical people, they would be the political opponents of the village head.

Further, problems related to accountability must be carried out in an open forum. It can be seen that the village government has reported the development through open forums such as mosques and notice boards. However, for the full budget management report, it is only limited to the village development office. The results of the study indicate that forums for submitting government accountability reports to public are carried out in mosques and informal village events. Whereas formally, the accountability report of village government should be submitted to village meeting, but government only reports the previous year of government administration along with the use of the budget. However, from the results of interviews with the community, forums like this are usually carried out on a limited basis.

The third problem is the weak monitoring function of BPD. Supervision aims to ensure that what is planned goes as it should. In other words, supervision ensures that what is done is by what should be done. In the concept of village government, there are several oversights carried out starting from inherent supervision by village head, BPD, local and central government, and functional supervision by BPK to public supervision by the community. For the supervision by village head, the research results have shown that supervision is carried out by the village head regarding the finance of village funds through a coordination meeting, directly down the field and looking at the process of village financial expenditure. For supervision by BPD, the results of the study showed that supervision is carried out generally through accountability reports and monitoring of development results by APBDs priority directives. However, BPD members from several villages were still unaware of their duties, so that the supervision they did was not effective.

From some forms of supervision to the village government, it seems that supervision by the local and central government has the most influence on village government. The village government is seriously preparing financial management accountability reports for hundreds or even thousands of sheets. For village communities and the BPD, village governments do not prepare special accountability reports. The village government only allows village communities to access the financial reports they have prepared for the district government or central government. With an average of relatively low educational level, such a full report will undoubtedly be difficult for the village community and BPD members to understand. That is why the village government should make simpler reports as the APBDs announced through banners or billboards. However, it seems that such hopes are still not possible to be realised by the village government because there has been no public demand to require financial statements to be announced to village community.

\section{Conclusion}

The practice of village financial management shows a tendency to place more emphasis on administrative accountability and override public accountability. The village government prioritizes accountability reports to local and central government rather than to the community. We have carried out some analyses by identifying problems with institutional mechanisms and citizenship 
forums. These two main issues focus on three factors: institutional relations in village governance, the way social organizations work in local communities, and cultures.

In conclusion, these three factors influence institutional mechanisms and citizenship forums in the village. In practice, these three factors differ from each other in determining the level of accountability in each village. However, in principle, those are the main characteristics of the weak presence of good governance in the community and village government. If the government and the village community can optimize these three factors, it will increasingly determine the level of public accountability in the village. The tendency of the village government to be more obedient to the government above it, on the one hand, is a challenge to public accountability, but on the other hand, it can also be used to encourage public accountability. The central government has normatively directed the village government financial accountability report to be submitted in writing to the village community. The regulation needs to be further socialized by district government to village government in the form of regulations or circulars.

Furthermore, it needs to be emphasized, so that the accountability report is submitted to the village community in a simple and easily accessible form. Public access to village government accountability reports must be built through joint agreements with the BPD and village communities. This simple recommendation is believed to be the first step in increasing public accountability at the village government level.

\section{References}

Antlöv H. (2003). Village Government and Rural Development in Indonesia: the New Democratic Framework. Bulletin of Indonesian Economic Studies 39 (2), 193-214.

Antlöv, H., Wetterberg, A., \& Dharmawan L. (2016). Village Governance, Community Life, and the 2014 Village Law in Indonesia. Bulletin of Indonesian Economic Studies 52 (2), 161-183.

Bebbington, A., Dharmawan, L., Fahmi, E., \& Guggenheim, S. (2004). Village Politics, Culture and Community-Driven Development: Insights from Indonesia. Progress in Development Studies 4 (3), 187-205.
Bebbington, A., Dharmawan, L., Fahmi, E., \& Guggenheim, S. (2006). Local Capacity, Village Governance, and the Political Economy of Rural Development in Indonesia. World Development 34 (11), 1958-1976.

Berenschot W. \& Sambodho P. (2017). The village head as patron. Inside Indonesia 128: Apr-Jun 2017.

Bovens, M. (2007). Analysing and Assessing Accountability: A Conceptual Framework. European Law Journal 13 (4), 447-468.

Bovens, M. (2010). Two Concepts of Accountability: Accountability as a Virtue and as a Mechanism. West European Politics 33 (5), 946-967.

Bovens, M., Schillemans, T., \& Goodin, R. E. (2014). "Public Accountability". In M. Bovens, R. E. Goodin, T. Schillemans (eds.) The Oxford Handbook of Public Accountability. New York: Oxford University Press.

Haryanto (2017). Adaptation and Continuities in Clientelism in a Fishing Community in Takalar, South Sulawesi. Contemporary Southeast Asia 39 (3), 511-531.

Klofstad, C. A. (2011). Civic Talk: Peers, Politics, and The Future of Democracy. Philadelphia: Temple University Press.

Lindberg, S. I. (2013). Mapping Accountability: Core Concept and Subtypes. International Review of Administrative Sciences 79 (2), 202-226.

Loozekoot, A. \& Dijkstra, G. (2015). Public accountability and the Public Expenditure and Financial Accountability tool: an assessment. International Review of Administrative Sciences 83 (4), 806-825.

McKinney, J. B. (1981). Process Accountability and the Creative Use of Intergovernmental Resources. Public Administration Review 41, 144-149.

Normanton, E. L. (1966). The Accountability and Audit of Governments. Manchester: Manchester University Press.

Novrizal, M. \& Podger, O. (2014). Corruption Prevention in Village Finance Governance. Paper presented at the University of Andalas and KPK Conference, Padang, 5-6 June.

O'Loughlin, M. G. (1990). Bureaucratic Accountability and How to Measure It? Administration and Society 22 (3), 275302.

Putnam, R. D. (1993). Making Democracy Work: Civic Traditions in Modem Italy. New Jersey: Princeton University Press.

Salim, A., Bulan, W.R., Untung, B., Laksono, I., \& Brock, K. (2017). Indonesia's Village 
Law: Enabler or Constraint for more Accountable Governance? Making All Voices Count Research Report. Brighton: IDS.

Schedler, A. (1999). "Conceptualizing Accountability". In Schedler, A., Diamond, L. \& Plattner, M. F. (eds.) The Selfrestraining State: Power and Accountability in New Democracies. Boulder, CO: Lynne Rienner.

Schmitter, P. \& Karl, T. L. (1991). What democracy is and is not. Journal of Democracy 3 (1): 75-88.

Smith, B. \& Hague, D. C. (1971). The Dilemma of Accountability in Modern Government: Independence versus Control. London: Macmillan.

Susan, N. \& Budirahayu, T. (2018). "Village Government Capacity in the Implementation of Village Law No. 6 of
2015 in Indonesia". In B. McLellan (ed.) Sustainable Future for Human Security. Singapore: Springer Singapore.

Sutiyo \& Maharjan, K. L. (2014). "Capacity of Rural Institutions in Implementing Decentralized Development in Indonesia: Case of Three Villages in Purbalingga District, Central Java Province". In K. L. Maharjan (ed.) Communities and Livelihood Strategies in Developing Countries. Tokyo: Springer Japan.

Sutiyo \& Maharjan, K. L. (2017). Decentralisation and Rural Development in Indonesia. Singapore: Springer Singapore. Vel, J. A. C., Berenschot, W., \& Minarchek, W. D. (2016). Report of the Workshop "New Law, New Villages? Changing Rural Indonesia", KITLV, Leiden. Available from: http://www.kitlv.nl/workshop-new-lawnew-villages-changing-rural-indonesia/. 